\title{
Predictive Value of Red Cell Distribution Width and Mean Platelet Volume in the Diagnosis and Determination of Severity in Acute Appendicitis Cases
}

\author{
Akut Apandisit Olgularında Eritrosit Dağılım Genişliği ve Ortalama Trombosit \\ Hacminin Tanıda ve Hastalığın Şiddetini Belirlemedeki Prediktif Değeri
}

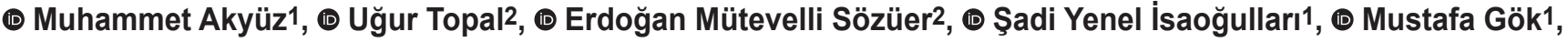 \\ (1) Türkmen Bahadır Arıkan1
}

${ }^{1}$ Erciyes University Faculty of Medicine, Department of General Surgery, Kayseri, Turkey

2Erciyes University Faculty of Medicine, Department of Surgical Oncology, Kayseri, Turkey

\section{HIIIIII| ABSTRACT}

\begin{abstract}
Aim: We aimed to determine the clinical value of erythrocyte distribution width (RDW) and mean platelet volume (MPV) in the diagnosis of acute appendicitis (AA) and in determining the severity of the disease.

Method: Patients who were operated between January 2013 and January 2020 with a preliminary diagnosis of AA were included in the study. The patients were divided into two groups as Group 1 negative appendectomy and Group 2 acute appendicitis. In addition, Group 2 is divided into subgroups as a:perforated and b: non-perforated. RDW and MPV were compared between the groups and subgroups.

Results: A total of 861 patients participated in our study. Group 1 consisted of 144 patients and Group 2 consisted of 717 patients. The mean age was similar in both groups (33.02 vs 35.34, p=0.088), female sex was higher in Group 1 ( $52.8 \%$ vs 42.9, p=0.019), RDW was higher in Group 1 (14.03 vs 13.67, p=0.007), MPV was similar between the groups (8.81 vs 8.95, p=0.363). RDW was an independent risk factor in the diagnosis of AA in multivariate analysis (odds ratio $0.604,95 \%$ confidence interval (minimum-maximum) 0.420-0.868, p=0.006). RDW and MPV were independent variables in the diagnosis of perforated appendicitis in multivariate logistic regression analysis.

Conclusion: RDW is a useful parameter in the diagnosis of AA and in determining the severity of the disease. However, MPV value does not have sufficient diagnostic value.
\end{abstract}

Keywords: Acute appendicitis, MPV, RDW, sensitivity, specificity

\section{|IIIIIII|| ÖZ}

Amaç: Eritrosit dağılım genişliğinin (RDW) ve ortalama trombosit hacminin (MPV) akut apandisit tanısındaki ve hastalığın şiddetini belirlemedeki klinik değerini saptamayı amaçladık.

Yöntem: Ocak 2013 ile ocak 2020 tarihleri arasında akut appendisit ön tanısı ile opere edilen hastalar çalışmaya dahil edildi. Hastalar Grup 1 negatif appendektomi; Grup 2 akut apandisit olmak üzere iki gruba ayrıldı. Ayrıca Grup 2a: Perfore ve 2b: nonperfore olmak üzere subgruplara ayrıldı. Nötrofil sayısı, RDW ve MPV oranları gruplarda ve subgruplarda karşılaştırıldı.

Bulgular: Çalışmamıza 861 hasta dahil edildi. Grup 1: 144, Grup 2: 717 hastadan oluşuyordu. Yaş ortalaması (33,02 vs 35,34 p=0,088) ve MPV oranları (8,81 vs 8,95 p=0,363) açısından her iki grup arasında anlamlı farklılık yoktu. Grup l'de kadın cinsiyet oranı daha yüksekti (\%52,8 vs 42,9 p=0,019). Ayrıca RDW oranları Grup l'de daha yüksekti (14,03\% vs 13,67\% p=0,007) ve RDW oranları multivaryant analizde akut appendisit tanısında bağımsız bir göstergeydi (odds ratio: 0,604 \%95 confidence interval: (minimum-maksimum) 0,420-0,868 p=0,006). RDW ve MPV oranları çok değişkenli lojistik regresyon analizinde perfore appendisit tanısında bağımsız değişkenlerdi.

Sonuç: Akut appendisit tanısında ve hastalığın şiddetinin belirlemesinde RDW yararlı bir parametredir. Fakat MPV değerinin yeterli tanısal değeri yoktur.

Anahtar Kelimeler: Akut appendisit, MPV, RDW, sensivite, spesivite 


\section{Introduction}

Acute appendicitis (AA) is the most common cause of acute surgical abdominal pain and is usually seen in patients in their 20s and 30s. ${ }^{1}$ In the literature, the lifetime prevalence of this disease is approximately $7 \%$, and its perforation rate is between $17 \%$ and $20 \%{ }^{2,3}$

Timely diagnosis is very important, since a diagnostic delay is associated with increased risk of perforation and potentially peritonitis, sepsis and death. On the contrary, negative appendectomy is associated with unnecessary risks and costs. Although advanced diagnostic tests and imaging methods have been developed, the rate of false diagnosis is still high. ${ }^{4,5}$

Complete blood count is used as part of the routine testing for AA. Based on this, many parameters in complete blood count and the combination of these parameters in the diagnosis of AA were investigated. ${ }^{6,7}$

The red blood cell distribution width (RDW) is a well-known erythrocyte parameter that shows variations in the diameter of red blood cells. At present, the erythrocyte index, which has been used in haematology practice, is accepted as a biological marker related to inflammation. A high RDW is associated with an increase in erythrocyte sedimentation rate and interleukin-6 levels. ${ }^{8}$

The mean platelet volume (MPV) is reported to be related to platelet function. The platelet size is closely related to platelet activity and function. Large platelets are more active than small platelets, and the MPV has been shown to reflect inflammatory burden. ${ }^{9}$

Recent studies have investigated on whether RDW and MPV can be used as an early predictor in AA. ${ }^{10,11,12}$ In this study, we aimed to determine the clinical value of RDW and mean MPV in the diagnosis of AA and in determining its severity.

\section{Materials and Methods}

Patients who underwent surgery with a preliminary diagnosis of AA between January 2013 and January 2020 in the Erciyes University Faculty of Medicine General Surgery Clinic were included in the study. This retrospective study was approved by the Erciyes University Institutional Review Board (no: 2020/251, dated: 20.05.2020). Files and hospital information system records were examined, and the cases were analysed retrospectively.

While patients who underwent appendectomy (both open and laparoscopic appendectomy) were included, patients aged $<18$ years; pregnant patients; patients with heart failure, haematological disease, cancer, chronic infectious disease, liver disease, vascular disease, infection or inflammatory disease; patients who had missing data; or patients taking drugs that may affect the platelet count and volume were excluded from the study.
Patients were divided into two groups according to the histopathological evaluation. The first group included patients with a normal appendix (negative appendectomy group), and the second group was composed of patients with AA (AA group), which was further subdivided into perforated and non-perforated appendicitis groups. Demographic data of patients such as age and sex and preoperative laboratory findings on admission [neutrophil count $/ \mathrm{mm}^{3}$, RDW (\%) and MPV (fL)] were compared between the negative appendectomy group and AA group. The same parameters were compared within the subgroups. The complete blood count was measured by an automated haematology analyser (Roche Hitachi Cobas ${ }^{\circledR} 8000$ Roche Diagnostics, Indianapolis, IN, USA). Reference values were 2-7x10 $/ \mathrm{L}$ for neutrophils, $7.4-10.4$ femtoliter (fL) for MPV and $11.6 \%-14 \%$ for RDW.

\section{Statistical Analysis}

SPSS (Statistical Package for the Social Sciences) 23.0 package programme was used in the statistical analysis of data. Categorical measurements were summarised as numbers and percentages and continuous measurements as mean and standard deviation (median and minimum-maximum where necessary). Pearson chi-square test statistics were used to compare categorical variables. Shapiro-Wilk test was used to determine whether the study parameters showed normal distribution. In comparing continuous measurements between groups, distributions were checked; independent Student's t-test was used for parameters with normal distribution, and the Mann-Whitney $\mathrm{U}$ test was used for parameters without normal distribution. In this study, the cut-off value was determined by calculating the sensitivity and specificity values based on the neutrophil count, RDW and MPV and by examining the area under the receiver operating characteristics (ROC) curve. Logistic regression analysis was employed to determine the independent variables that affect the dependent variables. Statistical significance level was taken as 0.05 in all tests.

\section{Results}

A total of 861 patients participated in our study. The negative appendectomy group consisted of 144 patients, and the AA group consisted of 717 patients. The mean age was similar in both groups ( 33.02 vs $35.34, \mathrm{p}=0.088$ ), female patients comprised most the negative appendectomy group (52.8\% vs $42.9, \mathrm{p}=0.019)$, the neutrophil count was higher in the AA group (8.20 vs 10.31, $\mathrm{p}=0.00$ ), RDW was higher in the negative appendectomy group ( $14.03 \%$ vs $13.67 \%, \mathrm{p}=0.007$ ) and MPV was similar between the two groups ( 8.81 vs 8.95 , $\mathrm{p}=0.363$ ). In the multivariate logistic regression analysis, neutrophil count and RDW were independent variables 
in the diagnosis of AA. Comparison results between the negative appendectomy and AA groups are detailed in Table 1. The ROC curve analyses of these independent variables are shown in Figure 1. The recommended cut-off and diagnostic values for these variables are shown in Table 2.

The perforated and non-perforated subgroups were composed of 65 and 652 patients, respectively. While the mean age was higher in the perforated subgroup (42.63 vs 34.62, $\mathrm{p}=0.00)$, sex distributions were similar $(\mathrm{p}=0.33)$. No significant difference was found between the groups in terms of neutrophil count (11.12 vs $10.23, \mathrm{p}=0.143$ ), RDW (13.98\% vs $13.64 \%, \mathrm{p}=0.056)$ and MPV ( 8.74 vs 8.97 , $\mathrm{p}=0.301$ ). In the multivariate logistic regression analysis, neutrophil count, RDW and MPV were independent variables in the diagnosis of perforated appendicitis. The comparison between the perforated and non-perforated subgroups is detailed in Table 3. The ROC curve analyses of these independent variables are shown in Figure 2.
The recommended cut-off and diagnostic values for these variables are shown in Table 4.

\section{Discussion}

Appendicitis is still the most common indication of emergency surgery. Traditionally, appendectomies are performed immediately after diagnosis was made to prevent the progression of inflammation and potential complications. ${ }^{13}$

Although leukocyte count generally increases in patients with AA, it is not a specific marker of AA and can increase in many diseases accompanied with inflammation during differential diagnosis. In AA, neutrophilia and left shift on the haemogram are often associated with lymphopaenia. ${ }^{14,15}$ Anderson reported a sensitivity of $71 \%-89 \%$ and specificity of $48 \%-80 \%$ in his meta-analysis (neutrophil count $>6,500 /$ $\left.\mathrm{mm}^{3}\right) \cdot{ }^{14}$

Table 1. Comparison of the two groups

\begin{tabular}{|c|c|c|c|c|c|c|c|c|c|}
\hline \multirow{2}{*}{$\begin{array}{l}\text { Parameters } \\
\text { Negative } \\
\text { appendectomy }\end{array}$} & \multicolumn{3}{|c|}{ Univariate analysis } & \multicolumn{3}{|c|}{ Multivariate analysis } & \multicolumn{3}{|c|}{ ROC curve analysis } \\
\hline & $\begin{array}{l}\text { Acute } \\
\text { appendicitis }\end{array}$ & $\mathrm{p}$ & OR & $\begin{array}{l}95 \% \mathrm{CI} \\
(\min - \\
\max )\end{array}$ & $\mathrm{p}$ & AUC & $\begin{array}{l}95 \% \mathrm{CI} \\
(\mathrm{min}- \\
\max )\end{array}$ & $\mathrm{p}$ & \\
\hline Patient number & $144(16.7)$ & $717(83.3)$ & & & & & & & \\
\hline \multirow{2}{*}{ Sex } & $68(47.2)$ & $409(57.1)$ & \multirow{2}{*}{0.019} & & & & & & \\
\hline & $76(52.8)$ & 307 (42.9) & & 1.489 & $1.040-2.132$ & 0.030 & & & \\
\hline $\begin{array}{l}\text { Neutrophil } \\
\left(\mathrm{x} 10^{3} / \mathrm{mm}^{3}\right)\end{array}$ & $\begin{array}{l}8.20 \pm 4.59 \\
(1.31-29.16)\end{array}$ & $\begin{array}{l}10.31 \pm 4.70 \\
(1.75-78)\end{array}$ & 0.000 & 3.846 & $2.652-5.576$ & 0.000 & 0.654 & $0.622-0.686$ & 0.001 \\
\hline MPV (Fl) & $\begin{array}{l}8.81 \pm 1.64 \\
(6.2-13.9)\end{array}$ & $\begin{array}{l}8.95 \pm 1.71 \\
(4.8-13.5)\end{array}$ & 0.363 & 1.365 & $0.954-1.954$ & 0.089 & 0.527 & $0.493-0.561$ & 0.291 \\
\hline
\end{tabular}

RDW: Red blood cell distribution width, MPV: Mean platelet volume, AUC: Area under the curve, OR: Odds ratio

Table 2. Proposed cut-off values for significant parameters in the diagnosis of acute appendicitis

$\begin{array}{llllllrr} & \text { Cut-off value } & \text { Sensitivity (\%) } & \begin{array}{l}\text { Specificity } \\ (\%)\end{array} & \text { PPV } & \text { NPV } & \text { OR } & \text { AUC } \\ \text { Neutrophil }\left(\mathrm{x} 10^{3} / \mathrm{mm}^{3}\right) & <7.04 & 52.08 & 77.96 & 32.2 & 89.0 & 5.716 & 0.654 \\ \text { RDW (\%) } & >13.9 & 43.75 & 69.32 & 22.3 & 86 & 2.194 & 0.560 \\ \text { MPV (Fl) } & <8.4 & 50.69 & 57.04 & 19.2 & 85.2 & 1.055 & 0.527\end{array}$

RDW: Red blood cell distribution width, MPV: Mean platelet volume, AUC: Area under the curve, PPV: Positive predictive value, NPV: Negative predictive value, OR: Odds ratio 

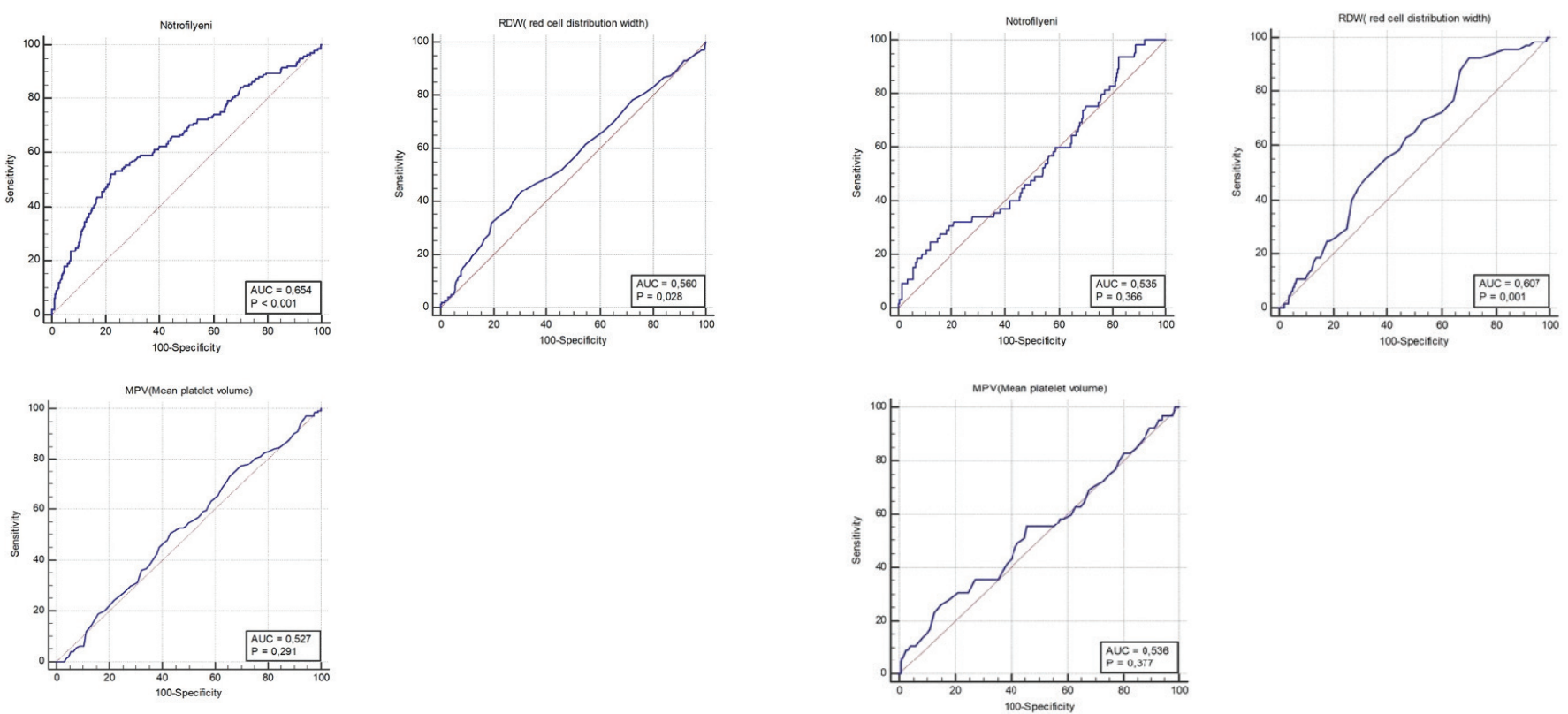

Figure 1. Receiver operating characteristic curve analyses of significant parameters for the diagnosis of acute appendicitis: (a) neutrophil count, (b) red blood cell distribution width and (c) mean platelet volume

Figure 2. Receiver operating characteristic curve analyses of significant parameters for the diagnosis of perforated appendicitis: (a) neutrophil count, (b) red blood cell distribution width and (c) mean platelet volume

Table 3. Comparison of the subgroups of the acute appendicitis group

\begin{tabular}{|c|c|c|c|c|c|c|c|c|c|}
\hline \multirow{2}{*}{$\begin{array}{l}\text { Parameters } \\
\text { Perforated }\end{array}$} & \multicolumn{3}{|c|}{ Multivariate analysis } & \multicolumn{6}{|c|}{ ROC curve analysis } \\
\hline & $\begin{array}{l}\text { Non- } \\
\text { perforated }\end{array}$ & $\mathrm{p}$ & OR & $\begin{array}{l}95 \% \text { CI } \\
(\min -\max )\end{array}$ & $\mathrm{p}$ & AUC & $\begin{array}{l}95 \% \mathrm{CI} \\
(\min - \\
\max )\end{array}$ & $\mathrm{p}$ & \\
\hline Patient number & $65(9.1)$ & $652(90.9)$ & & & & & & & \\
\hline Age & $\begin{array}{l}42.63 \pm 18.26 \\
(19-85)\end{array}$ & $\begin{array}{l}34.62 \pm 14.57 \\
(13-87)\end{array}$ & 0.000 & & & & & & \\
\hline Male & $35(53.8)$ & $374(57.5)$ & & & & & & & \\
\hline Female & $30(46.2)$ & $277(42.5)$ & 0.333 & 1.157 & $0.694-1.931$ & 0.576 & & & \\
\hline $\begin{array}{l}\text { Neutrophil } \\
\left(\times 10^{3} / \mathrm{mm}^{3}\right)\end{array}$ & $\begin{array}{l}11.12 \pm 4.74 \\
(4.63-27.78)\end{array}$ & $\begin{array}{l}10.23 \pm 4.69 \\
(1.75-78)\end{array}$ & 0.143 & 0.416 & $0.226-0.767$ & 0.005 & 0.535 & $0.498-0.572$ & 0.366 \\
\hline RDW (\%) & $\begin{array}{l}13.98 \pm 1.22 \\
(11.8-17.9)\end{array}$ & $\begin{array}{l}13.64 \pm 1.37 \\
(11.5-20.7)\end{array}$ & 0.056 & 0.197 & $0.078-0.497$ & 0.001 & 0.607 & $0.570-0.642$ & 0.001 \\
\hline MPV (Fl) & $\begin{array}{l}8.74 \pm 1.83 \\
(5.6-12.3)\end{array}$ & $\begin{array}{l}8.97 \pm 1.7 \\
(4.8-13.5)\end{array}$ & 0.301 & 2.026 & $1.119-3.669$ & 0.020 & 0.536 & $0.498-0.573$ & 0.377 \\
\hline
\end{tabular}

RDW: Red blood distribution width, MPV: Mean platelet volume, AUC: Area under the curve, OR: Odds ratio, min: Minimum, max: Maximum, CI: Confidence interval

Table 4. Proposed cut-off values for significant parameters in prediction of perforation

$\begin{array}{lllllrrr} & \text { Cut-off value } & \begin{array}{l}\text { Sensitivity } \\ (\%)\end{array} & \begin{array}{l}\text { Specificity } \\ (\%)\end{array} & \text { p } & \text { PPV } & \text { NPV } & \text { AUC } \\ \text { Neutrophil }\left(\mathrm{x} 10^{3} / \mathrm{mm}^{3}\right) & >14.57 & 24.62 & 88.04 & 0.366 & 17.0 & 92.1 & 0.535 \\ \text { RDW (\%) } & >12.8 & 92.31 & 29.75 & 0.001 & 11.6 & 97.5 & 0.607 \\ \text { MPV (Fl) } & <7.1 & 26.15 & 85.12 & 0.377 & 14.9 & 92.0 & 0.536\end{array}$

RDW: Red blood cell distribution width, MPV: Mean platelet volume, AUC: Area under the curve, PPV: Positive predictive value, NPV: Negative predictive value, OR: Odds ratio 
In our study, the neutrophil count was higher in the AA group ( $\mathrm{p}=0.000$ ). For the cut-off value [area under the curve (AUC) $0.654 ; 95 \%$ confidence interval (CI) 622-0.684, $\mathrm{p}=0.001]$ determined according to the ROC curve, the sensitivity and specificity were $52 \%$ and $77 \%$, respectively. RDW is frequently used in haematology practice to distinguish iron deficiency anaemia from other microcytic anaemias. Increased RDW is associated with erythropoiesis disorder or erythrocyte destruction. RDW has also been investigated in inflammatory and infectious pathologies such as rheumatoid arthritis, inflammatory bowel disease, colon cancer and celiac disease. RDW elevations have been shown to be associated with increased levels of inflammatory markers such as C-reactive protein (CRP), erythrocyte sedimentation rate and interleukin-6. Proinflammatory cytokines in sepsis negatively affect the life span of circulating erythrocytes and suppress erythrocyte maturation. ${ }^{12,16}$

In the study by Narci et al. ${ }^{10}$, RDW was significantly lower in the AA group than in the control group $(15.4 \pm 1.5$ vs $15.9 \pm 1.4, \mathrm{p}=0.001$ ). In the ROC analysis, the diagnosis of AA with $15.6 \%$ cut-off for RDW had sensitivity of $47 \%$ and specificity of $67 \%$ (AUC 0.62). ${ }^{11}$ Günay et al. ${ }^{17}$ compared complicated and non-complicated AA cases and reported that the RDW was higher in the complicated appendicitis group $(16.97 \pm 4.48$ vs $14.28 \pm 2.73, p=0.001)$. In the same study, RDW was determined as an independent diagnostic factor for complicated appendicitis in the logistic regression analysis (OR: 1.412, 95\% CI: 1.01-1.98, p=0.046). ${ }^{17}$ In the study by Boshnak et al. ${ }^{18}$, unlike the literature, no difference was found in the RDW of the negative and positive appendectomy groups $(13.13 \pm 0.36$ vs $13.06 \pm 0.43$, $p>0.05)$. However, in their study, RDW was higher in complicated AA cases $(13.02 \pm 0.40$ vs $13.30 \pm 0.58, p=0.006) .{ }^{18}$ Tanrikulu et al. ${ }^{19}$ reported no significant relationship between RDW and AA, similar to the finding of Boshnak et al. ${ }^{18}$

Bozlu et al. ${ }^{20}$ reported that RDW was elevated in children with AA, but they did not find a significant difference in complicated cases. In this study, the diagnostic value of RDW in children with AA was not higher than that of white blood cells or CRP. They concluded that a high RDW is valuable in the diagnosis of AA in children, but it is not a useful marker for complicated appendicitis. ${ }^{20}$

In our series, RDW was higher in the negative appendectomy group ( $14.03 \%$ vs $13.67 \%, \mathrm{p}=0.007)$. RDW was an independent risk factor for AA in the multivariate analysis. When the cut-off value was 13.9, RDW showed $43 \%$ sensitivity and $69 \%$ specificity in the diagnosis of AA. RDW was similar in the perforated and non-perforated appendicitis subgroups. In the multivariate analysis, it was an independent risk factor for perforated appendicitis.
When the cut-off value was 12.8, RDW demonstrated 92\% sensitivity and $29 \%$ specificity.

During the development of sepsis, platelets are thought to be one of the first responding anuclear cells. Gurler and Aktas $^{21}$ suggested that the increase or decrease in MPV in inflammatory conditions results from the effects of inflammatory cytokines in the bone marrow. Active platelets grow in infectious conditions and cause an increase in MPV in haemogram tests. However, after the use of larger activated platelets in inflammatory processes, smaller platelets lead to a decrease in MPV in blood count tests. ${ }^{21}$ Increases in MPV are associated with chronic diseases, and decreases are associated with acute diseases. While increased MPV were observed in chronic disease conditions, decreased MPVs were observed in acute disease environments. In the literature, low MPVs during an attack increased to normal levels in patients with ankylosing spondylitis and rheumatoid arthritis. In addition, in some inflammatory bowel diseases, MPV decreased in parallel with increased disease activity. ${ }^{22,23}$ However, the pathophysiological mechanisms for decreased MPV in patients with AA is not yet clear. ${ }^{24}$

Discussions are on-going in studies that have investigated the diagnostic value of MPV. Erdem et al. ${ }^{5}$ reported MPVs for the AA group and control group as $7.4 \pm 0.9$ (5.6-10.6) fL vs $9.1 \pm 1.6(5.1-13.1) \mathrm{fL}$, respectively $(\mathrm{p}<0.001)$. In their ROC analysis, the AUC was $82.4 \%$ for the MPV. When the cut-off MPV value was below $7.95 \mathrm{fL}$, the test's sensitivity and specificity were $74 \%$ and $75 \%$, respectively. ${ }^{25}$ In the study by Narci et al., the median MPV was $7.92 \pm 1.68 \mathrm{fL}$ in the AA group and $7.43 \pm 1.34 \mathrm{fL}$ in the control group. The MPV was significantly higher in the AA group than in the control group $(\mathrm{p}<0.001)$. In their ROC analysis, the AUC was $62 \%$, and with a cut-off value of 7.87 , the sensitivity and specificity were $66 \%$ and $51 \%$, respectively. ${ }^{10}$ Uyanik et al. ${ }^{26}$ concluded that MPV in the paediatric age group was similar in the AA and control groups $(7.9 \pm 0.9$ vs $7.7 \pm 0.8$, $\mathrm{p}>0.05$ ) and had no diagnostic value for AA. ${ }^{26}$ Similarly, Dinc et al. found a sensitivity of $29.5 \%$, specificity of $49.0 \%$ and diagnostic accuracy of $34.0 \%$ for MPV, but with limited diagnostic value. ${ }^{24}$ However, on separate evaluation, these studies have heterogeneous characteristics. In the most recent meta-analysis for the diagnostic value of MPV in AA, MPV decreased significantly in patients with AA compared with the control group (weighted mean difference, -0.64; $95 \% \mathrm{CI},-0.74$ to $-0.54 ; \mathrm{p}=0.037$ ). The analysis showed that MPV can be used as a biomarker for AA, but it does not have sufficient diagnostic value. ${ }^{27}$

Yardimcı et al. ${ }^{28}$ found higher MPV values in patients with AA than in healthy controls $(9.3 \pm 8$ vs $9.3 \pm 8, \mathrm{p}=0.0005)$. In the same study, according to the pathologies in the patient group, the MPV was $8.8 \pm 5.8$ (6-96) for phlegmonous 
appendicitis, $8.9 \pm 5.8$ (6.1-74) for localised peritonitis and 12.8 \pm 9.7 (6.7-87) for perforation and/or gangrenous appendicitis. They found a statistically significant difference between patient groups (95\% CI 8.5-10.1; $\mathrm{p}=0.005$ ). Another outcome of this study was to identify the role of MPV in predicting more severe forms of AA, such as perforation and/ or gangrenous appendicitis. According to the ROC analysis, when the cut-off value was 8.92 in the differential diagnosis of AA, it has $73 \%$ sensitivity and $57 \%$ specificity (AUC 0.57 ; 95\% CI 0.49-0.62; $\mathrm{p}=0.0005){ }^{28}$

In our series, MPV did not differ significantly between the negative appendectomy group and AA group or between perforated and non-perforated groups. Moreover, MPV has no diagnostic value for either AA or perforated appendicitis.

\section{Study Limitations}

The most important limitation of this study was its retrospective nature. In addition, only patients who underwent appendectomy were included in the study, as patients suspected of AA who did not undergo surgery were excluded.

\section{Conclusion}

RDW is helpful in the diagnosis of AA and detection of perforated appendicitis, but it has no sufficient diagnostic value when used alone. Normal RDW values cannot exclude AA alone. MPV has a low clinical value in the diagnosis of $\mathrm{AA}$ and in the detection of perforated appendicitis.

\section{Ethics}

Ethics Committee Approval: After obtaining permission from the Ethics Committee of Erciyes university Faculty of Medicine dated 20.05.2020 and numbered 2020/251.

Informed Consent: Because the study was retrospective, we could not get informed consent.

Peer-review: Externally peer reviewed.

\section{Authorship Contributions}

Surgical and Medical Practices: M.A., U.T., E.M.S., Ş.Y.İ., M.G., T.B.A., Concept: M.A., U.T., S.Y.İ., Design: M.A., U.T., Data Collection or Processing: U.T., S.Y.İ, M.G., T.B.A., Analysis or Interpretation: M.A., U.T., E.M.S., Literature Search: U.T., M.G., T.B.A., Writing: M.A., U.T., E.M.S.

Conflict of Interest: No conflict of interest was declared by the authors.

Financial Disclosure: The authors declared that this study received no financial support.

\section{References}

1. Sert OZ. Polypropylene manual knotting for closure of appendix stump during laparoscopic appendectomy. Turk J Colorectal Dis 2017;27:72-75.
2. Pehlivanlı F, Aydin O. Role of platelet to lymphocyte ratio as a biomedical marker for the pre-operative diagnosis of acute appendicitis. Surg Infect 2019;20:631-636.

3. Kahramanca S, Ozgehan G, Seker D, Gökce EI, Seker G, Tunç G, Küçükpınar T, Kargıcı H. Neutrophil-tolymphocyte ratio as a predictor of acute appendicitis Ulus Travma Acil Cerrahi Derg 2014;20:19-22.

4. Aktimur R, Cetinkunar S, Yildirim K Ozdas S, Aktimur SH, Gokakin AK. Mean platelet volume is a significant biomarker in the differential diagnosis of acute appendicitis. Inflammation and Cell Signaling, 2015;2:e930.

5. Erdem H, Çetinkünar S, Daş K, Reyhan E, Değer C, Aziret M, Bozkurt H, Uzun S, Sözen S, İrkörücü O. Alvarado, Eskelinen, Ohhmann and Raja Isteri Pengiran Anak Saleha Appendicitis Scores for Diagnosis of Acute Appendicitis World J Gastroenterol 2013;19:9057-9062.

6. Sevinç MM, Kınacı E, Çakar E, Bayrak S, Özakay A, Aren A, Sarı S. Diagnostic value of basic laboratory parameters for simple and perforated acute appendicitis: an analysis of 3392 cases. Ulus Travma Acil Cerrahi Derg 2016;22:155-162

7. Yıldırım AC, Anuk T, Günal E, İrem B, Gülkan S. Clinical Value of the platelet-to-lymphocyte ratio for diagnosing complicated acute appendicitis. Turk J Colorectal Dis 2017;27:1-5.

8. Lippi G, Targher G, Montagnana M, Salvagno GL, Zoppini G, Guidi GC. Relation between red blood cell distribution width and inflammatory biomarkers in a large cohort of unselected outpatients. Arch Pathol Lab Med 2009;133:628-630.

9. Park Y, Schoene N, Harris W. Mean platelet volume as an indicator of platelet activation: methodological issues. Platelets 2002;13:301-306.

10. Narci H, Turk E, Karagulle E, Togan T, Karabulut K. The role of mean Platelet Volume in the Diagnosis of Acute Appendicitis: A Retrospective Case-Controlled Study. Iran Red Crescent Med J 2013;15:e11934.

11. Albayrak Y, Albayrak A, Albayrak F, Yildirim R, Aylu B, Uyanik A, Kabalar E, Güzel IC. Mean platelet volume: a new predictor in confirming acute appendicitis diagnosis. Clin Appl Thromb Hemost 2011;17:362-366.

12. Narci H, Turk E, Karagulle E, Togan T, Karabulut K. The role of red cell distribution width in the diagnosis of acute appendicitis: a retrospective case-controlled study. World J Emerg Surg 2013;8:46-52.

13. Aktürk OM, Çakır M, Yıldırım D, Akıncı M. C-reactive protein and red cell distribution width as indicators of complications in patients with acute appendicitis. Arch Clin Exp Med 2019;4:76-80.

14. Andersson RE. Meta-analysis of the clinical and laboratory diagnosis of appendicitis. Br J Surg 2004;91:28-37.

15. Eren T, Tombalak E, Burcu B, Özemir IA, Leblebici M, Ziyade S. Predictive value of neutrophil/lymphocyte ratio for the diagnosis and severity of disease in acute appendicitis. Dicle Med J 2016;43:279-284.

16. Sadaka F, O'Brien J, Prakash S. Red cell distribution width and outcome in patients with septic shock. J Int Care Med 2013;28:307-313.

17. Günay Y, Taşdöven İ, Kozan R, Koca Ş, Çağlar E. Investigation of predictive value of complete blood count in the diagnosis of acute complicated appendicitis. Med Bull Haseki 2019;57:26-31.

18. Boshnak N, Boshnaq M, Elgohary H. Evaluation of platelet indices and red cell distribution width as new biomarkers for the diagnosis of acute appendicitis. J Investi Surg 2018;31:121-129.

19. Tanrikulu CS, Tanrikulu Y, Sabuncuoglu MZ, Karamercan MA, Akkapulu N, Coskun F. Mean platelet volume and red cell distribution width as a diagnostic marker in acute appendicitis. Iran Red Crescent Med J 2014;16:e10211.

20. Bozlu G, Taskinlar H, Unal S, Alakaya M, Nayci A, Kuyucu N. Diagnostic value of red blood cell distribution width in pediatric acute appendicitis. Pediatr Int 2016;58:202-205.

21. Gurler M, Aktas G. A review of the association of mean platelet volume and red cell distribution width in inflammation. Int J Res Med Sci 2016;4:1-4. 
22. Kisacik B, Tufan A, Kalyoncu U, Karadag O, Akdogan A, Ozturk MA, Kiraz S, Ertenli I, Calguneri M. Mean platelet volume (MPV) as an inflammatory marker in ankylosing spondylitis and rheumatoid arthritis. Joint Bone Spine 2008;75:291-294.

23. Yüksel O, Helvaci K, Başar O, Köklü S, Caner S, Helvaci N, Abayli E, Altiparmak E. An overlooked indicator of disease activity in ulcerative colitis: mean platelet volume. Platelets 2009;20:277-281.

24. Dinc B, Oskay A, Dinc SE, Bas B, Tekin S. New parameter in diagnosis of acute appendicitis: Platelet distribution width. World J Gastroenterol 2015;14:1821-1826.

25. Erdem H, Aktimur R, Cetinkunar S, Reyhan E, Gokler C, Irkorucu O, Sozen S. Evaluation of mean platelet volume as a diagnostic biomarker in acute appendicitis. Int J Clin Exp Med 2015;8:1291-1295.
26. Uyanik B, Kavalci C, Arslan ED, Yilmaz F, Aslan O, Dede S. Role of mean platelet volume in diagnosis of childhood acute appendicitis. Emerg Med Int 2012;2012:823095.

27. Fan Z, Zhang Y, Pan J, Wang S. Acute appendicitis and mean platelet volume: A systemic review and meta-analysis. Ann Clin Lab Sci 2017;47:768-772.

28. Yardımcı S, Uğurlu MÜ, Coşkun M, Attaallah W, Yeğen ŞC. Neutrophillymphocyte ratio and mean platelet volume can be a predictor for severity of acute appendicitis. Ulus Travma Acil Cerrahi Derg 2016;22:163-168. 